(C) Поливач В. М., 2019 p.

http://orcid.org/0000-0003-0155-7284

DOI: $10.34142 / 23128046.2019 .46 .07$

В. М. Поливач

\title{
МЕТОДИКА ТА РОЛЬ ВИЗНАЧЕННЯ СУБ'ЄКТИВНОЇ ОЦНКИ ЯКОСТІ ФІЗИЧНОГО ВИХОВАННЯ СТУДЕНТІВ ФАКУЛЬТЕТУ ПІДГОТОВКИ ЛІКАРІВ ДЛЯ ЗБРОЙНИХ СИЛ УКРАЇНИ ЯК ФАКТОР ПОКРАЩЕННЯ СИСТЕМИ ОСВІТИ ВІЙСЬКОВИХ ЛІКАРІВ
}

Робота в надзвичайних ситуаиіях $i$ під час військових конфліктів призводить до значних фізичних і психологічних стресів, які вимагають від військового лікаря фундаментальних знань, відпрачьованих медичних навичок, фізичної $i$ психічної стабільності. 3 метою забезпечення ефективного функиіонування та виконання обов'язків лікаря в ичих умовах фізичне виховання має стати невід'ємною частиною навчальних програм військово-медичного персоналу. Стаття присвячена проблематиці оцінки рівня задоволеності студентами факультету підготовки лікарів для Збройних Сил Украӥни Національного медичного університету імені О. О. Богомольия дисиипліною «Фізичне виховання».

Дослідження було проведено з використанням украӥнської версії Student's Learning Satisfaction Questionnaire (SLSQ) та анкети автора, розробленої на основі SLSQ. Опитування було проведено протягом жовтня 2018 року. Загальна кількість респондентів складала 69 студентів з 3 по 5 роки навчання. Для статистичної обробки даних було використане лічензійне програмне забезпечення IBM SPSS Statistics v.22 з розрахунком середніх, медіанних, модних і процентних розподілів. Робота детально описує оригінальне дослідження, проведене з використанням міжнародного апробованого опитувальника та авторської анкети, розробленої на основі останнього, підтверджуючи можливість їхнього використання при проведенні наукових робіт.

Використана методика поєднання міжнародного апробованого опитувальника SLSQ та авторської анкети, розробленої за його принципами, дозволяе ефективно визначити рівень задоволеності студентів фізичної підготовкою під час навчання. Переважна більшість відповідей студентів

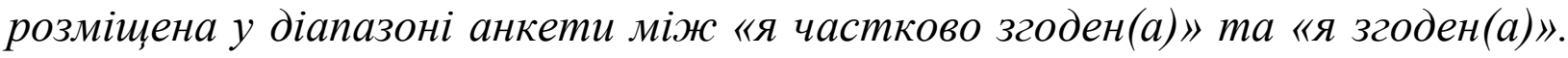
Таким чином, загальна задоволеність студентів дисиипліною «Фізична підготовка» знаходиться на середньому рівні; найвищі показники задоволеності студентів припали на групу питань, що описують взаємодію із викладачами; найнижчі показники задоволеності зареєстровані за 
категоріями матеріально-технічного забезпечення навчальних занять та професійно-орієнтованої підготовки.

Ключові слова: військова медицина, фізичне виховання, задоволеність студентів, реформування системи вищої освіти.

Polyvach V. M. Methodology and the role of determination of students' satisfaction with physical education on the faculty for training of doctors for the Armed Forces of Ukraine as a factor of improving the system of education of military doctors. Improvement of the professional training of military doctors in Ukraine has become very relevant in recent years. Working under emergency conditions and during military conflict leads to the significant physical and psychological stresses that require the military medical officer to have a thorough knowledge of medical skills, physical and mental stability. In order to ensure the effective functioning and fulfillment of the duties of a doctor in these circumstances, physical education should become an integral part of training programs of military medical personnel. The aim of the study is to evaluate the satisfaction of students of the Faculty for Training of Doctors for the Armed Forces of Ukraine of the Bogomolets National Medical University with the physical training during university studies. Material and methods: the study was conducted using the Ukrainian version of the Student's Learning Satisfaction Questionnaire (SLSQ) and author's questionnaire, developed on the base of SLSQ. The questionnaire was conducted during October 2018. Total number of respondents was 69 students that included student of 3-5 years of study. Statistical data processing was performed using IBM SPSS Statistics v.22 licensed software with the calculation of averages, median, mods, and percentage distributions. According to results, general satisfaction with the discipline "Physical education" was on average level; the highest levels of student satisfaction came from a group of questions that describe the interaction with teachers; the lowest rates of satisfaction were registered in the categories of material support of training sessions and professionally oriented training.

Keywords: military medicine, physical training, students' satisfaction, reforming the system of higher education.

Вступ. Удосконалення професійної підготовки військових лікарів в Україні набуло значної актуальності протягом останніх років. У даний час систему освіти військових медиків можна розділити на два рівні додипломний, що здійснюється на факультеті підготовки лікарів для Збройних Сил України у Національному медичному університеті імені О. О. Богомольця, та післядипломний - в Українській військово-медичній академії. 
Важливість інтегративного підходу при побудові освітніх програм для даного контингенту студентів та інтернів пов'язана із необхідністю забезпечення відмінної підготовки як у галузі медицини, так і різноманітних дисциплінах військової справи. Робота в умовах надзвичайних ситуацій та особливого стану несе у собі значні фізичні та психоемоційні навантаження, що вимагають від військового медика досконалого володіння медичними навичками, фізичною та психічною стійкістю. 3 метою забезпечення ефективного функціонування та виконання лікарем службових обов'язків у зазначених обставинах, невід'ємною частиною програм підготовки майбутніх військовослужбовців є фізичне виховання (Coffman \& Gilligan, 2002).

Водночас, відповідно до дослідження міжнародної аудиторської компанії з оцінки якості надання освітніх послуг QS Top University Rankings, задоволеність студентами навчанням у закладі вищої освіти, $є$ одним із основних визначальних показників його успішності вцілому (Why student satisfaction is key to the student recruitment, n. d.). Суб'єктивізація оцінки рівня підготовки в університеті є важливою стратегією розвитку закладу вищої освіти в умовах ринкової економіки. Це пов'язано із певною різницею у об’єктивних умовах навчання та їхнім сприйняттям кінцевим споживачем, яким у даному випадку виступає студент (Mason \& Weller, 2000).

Завершальний портрет, що формується у свідомості, піддається впливу внутрішніх особистісних факторів, таких як вихідні очікування, попередній життєвий досвід, особливості емоційно-вольової сфери, риси характеру (Dennis, Papagiannidis, Alamanos \& Bourlakis, 2016). Для студентів факультету підготовки лікарів для Збройних Сил України аспекти суб'єктивної оцінки рівня підготовки в університеті є особливо важливими, адже дана когорта формує кадровий потенціал вітчизняної армії, із першого університетського року свідомо обираючи кар'єру медика-військовослужбовця.

Фізичне виховання є невід'ємною частиною процесу підготовки будьякого військовослужбовця, у тому числі і мілітарного лікаря. Незважаючи на 
високу актуальність такої проблематики, як оцінки задоволеності студентів навчанням вцілому, так і окремо студентів факультету підготовки лікарів для Збройних Сил України, подібні дослідження в Україні раніше не проводилися. Налагодження «зворотного зв'язку» зі студентами є «золотим стандартом» розвитку системи вищої освіти у світі, а у сфері навчання військових лікарів повинно стати запорукою цілісного та всебічного розвитку студентів для гарантування їхньої ефективної роботи у майбутньому (Nauta, 2007).

Серед вітчизняних науковців проблематику фізичної підготовки студентів, як елементу професійно-прикладного навчання, у своїх дослідженнях розробляли Л. Пустолякова, М. Болгар, С. Павліченко, Е. Маляр, В. Будний, В. Жигачов, Р. Гринь (Pustoliakova, Bolhar \& Pavlichenko, 2014). Зокрема, Е. Маляр та В. Будний у висновках до свого дослідження зазначають, що «науково-технічний прогрес ставить до спеціаліста все складніші завдання, у зв'язку з чим зміст професійноприкладної фізичної підготовки фахівця повинен бути адаптований до вимог майбутньої професії; навчальна програма фізичного виховання студентів закладів вищої освіти містить загальні рекомендації щодо професійноприкладної фізичної підготовки студентів різних спеціальностей i не враховує особливостей їхньої майбутньої професійної діяльності» (Maliar \& Budnyi, 2009).

Задоволеність студентів як складова процесу вищої освіти фігурує у багатьох іноземних авторів. Серед них: В. Butt, K. Rehman, R. Mason. M. Weller, D. Coffman, T. Gilligan, K. Hong, M. Nauta, J. Richardson, K. Swan. Серед вітчизняних дослідників дана проблематика відображена у працях В. Кобець (Kobets, 2012; Butt \& Rehman, 2010).

Мета та завдання: оцінити задоволеність студентів факультету підготовки лікарів для Збройних Сил України Національного медичного університету імені О. О. Богомольця рівнем фізичної підготовки під час навчання. 
Методи дослідження: дослідження було проведено 3 використанням міжнародного апробованого опитувальника Students' Learning Satisfaction Questionnaire (SLSQ) (Topala \& Tomozii, 2014) та анкети, розробленої на основі останнього - табл. 1. Період проведення опитування - жовтень 2018 року.

У дослідженні брали участь студенти 3-5 курсів, загальна кількість респондентів склала 69 осіб.

Статистична обробка даних проводилася із використанням ліцензованого програмного забезпечення IBM SPSS Statistics v. 22 (ліцензія НМУ імені О. О. Богомольця) із підрахунком середніх значень, медіани, моди та екстенсивних показників розподілу вибірки.

Таблиця 1

Анкета для оцінювання задоволеності студентами факультету підготовки лікарів для Збройних Сил України дисципліною «Фізичне виховання».

\begin{tabular}{|c|c|c|c|c|c|c|}
\hline № & Запитання & \multicolumn{5}{|c|}{ Відповідь* } \\
\hline 1. & Кількість практичних занять достатня & 1 & 2 & 3 & 4 & 0 \\
\hline 2. & Тривалість практичних занять д & 1 & 2 & 3 & 4 & 0 \\
\hline 3. & Структура практичних занять 3 & 1 & 2 & 3 & 4 & 0 \\
\hline 4. & $\begin{array}{l}\text { Я ознайомлений із матеріалом, винесеним на самостійне } \\
\text { вивчення }\end{array}$ & 1 & 2 & 3 & 4 & 0 \\
\hline 5. & $\begin{array}{l}\text { Мені вдається ефективно опрацювати матеріал, винесений на } \\
\text { самостійне вивчення }\end{array}$ & 1 & 2 & 3 & 4 & 0 \\
\hline 6. & Наявний весь необхідний інвентар & 1 & 2 & 3 & 4 & 0 \\
\hline 7. & Спортивний зал обладнано комфортно & 1 & 2 & 3 & 4 & 0 \\
\hline 8. & Зовнішні майданчики обладнано комфортно & 1 & 2 & 3 & 4 & 0 \\
\hline 9. & Температура у спортивному залі комфортна & 1 & 2 & 3 & 4 & 0 \\
\hline 10. & Освітленість у спортивному залі достатня & 1 & 2 & 3 & 4 & 0 \\
\hline 11. & $\begin{array}{l}\text { Дисципліна дозволяє значно підвищити рівень моєї фізичної } \\
\text { підготовки }\end{array}$ & 1 & 2 & 3 & 4 & 0 \\
\hline 12. & Дисципліна сприяє загальному здоров’язбереженню & 1 & 2 & 3 & 4 & 0 \\
\hline 13. & Дисципліна дозволяє покращити вміння із різних видів спорту & 1 & 2 & 3 & 4 & 0 \\
\hline 14. & $\begin{array}{l}\text { Дисципліна дозволяє значно покращити вміння у конкретному } \\
\text { виді спорту }\end{array}$ & 1 & 2 & 3 & 4 & 0 \\
\hline
\end{tabular}




\begin{tabular}{|c|c|c|c|c|c|c|}
\hline 15. & Дисципліна дозволяє значно підвищити мою витривалість & 1 & 2 & 3 & 4 & 0 \\
\hline 16. & Дисципліна дозволяє значно підвищити мої силові якості & 1 & 2 & 3 & 4 & 0 \\
\hline 17. & Дисципліна дозволяє значно підвищити м & 1 & 2 & 3 & 4 & 0 \\
\hline 18. & Дисципліна дозволяє значно підвищити мою спритність & 1 & 2 & 3 & 4 & 0 \\
\hline 19. & Викладачі ставляться до мене із повагою & 1 & 2 & 3 & 4 & 0 \\
\hline 20. & Викладачі компетентні у відповідному матеріалі & 1 & 2 & 3 & 4 & 0 \\
\hline 21. & Я задоволений поточно (нормативною) системою оцінювання & 1 & 2 & 3 & 4 & 0 \\
\hline 22. & Мені вдається успішно скласти всі нормативи & 1 & 2 & 3 & 4 & 0 \\
\hline 23. & $\begin{array}{l}\text { Під час занять враховуються мої початкові рівні розвитку } \\
\text { певних навичок }\end{array}$ & 1 & 2 & 3 & 4 & 0 \\
\hline 24. & $\begin{array}{l}\text { Проходження дисципліни сприятиме ефективній роботі в } \\
\text { умовах бойових дій та надзвичайних ситуацій }\end{array}$ & 1 & 2 & 3 & 4 & 0 \\
\hline 25. & Під час занять використовуються стимуляційні методики & 1 & 2 & 3 & 4 & 0 \\
\hline 26. & $\begin{array}{l}\text { Під час занять проводиться навчання роботі в умовах бойових } \\
\text { дій та надзвичайних ситуацій }\end{array}$ & 1 & 2 & 3 & 4 & 0 \\
\hline \multicolumn{7}{|c|}{ 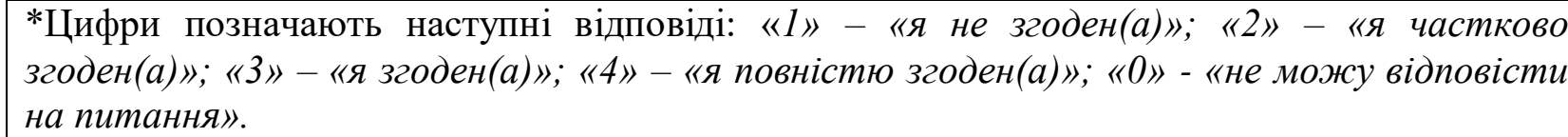 } \\
\hline
\end{tabular}

Додатково, до анкети було внесено два дихотомічні питання: «Чи необхідно модернізувати програму дисципліни «Фізичне виховання»?» та «Чи необхідно включити до програми дисципліни «Фізичне виховання»?».

Результати. Контингент респондентів за статевим розподілом складався із 55 чоловіків (80\%) та 14 жінок (20\%) - графік 1.

\section{Графік 1. Статевий розподіл}

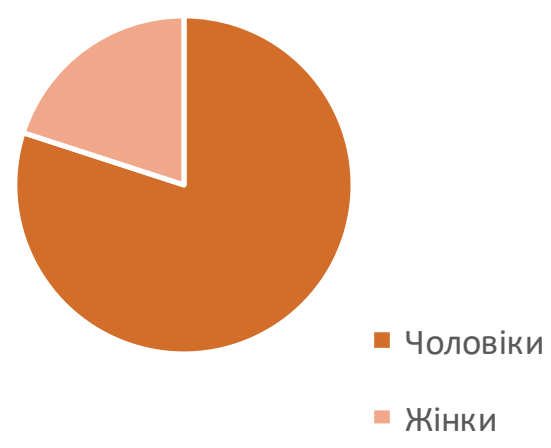

62 особи, тобто 89\% студентів вступали до НМУ імені О. О. Богомольця на основі документу про загальну середню освіту, а 7 осіб 11\%, після завершення середньої професійної освіти - графік 2. 
Графік 2. Базова освіта

респондентів

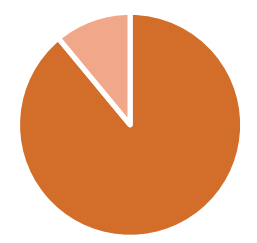

- Загальноосвітня школа

- Середня професійна освіта

Опитувані продемонстрували високий показник шкільної успішності: 50 осіб (72\%) студентів вказали, що мали відмінний середній бал документу про попередню освіту, 17 осіб (24\%) - добрий, і 2 особи, тобто 4\%, - середній - графік 3.

Графік 3. Середній бал документу про базову освіту

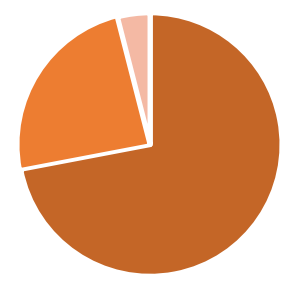

• "Відмінно" "Добре" - "Задовільно"

Такий розподіл свідчить про зацікавленість професією військового лікаря абітурієнтів із переважно високими здобутками у середній школі/закладі середньої професійної освіти.

3 метою підрахунку результатів анкети кожній із відповідей присвоювався бал за відповідною цифрою, де 1 - «я не згоден(а)»; 4 - «я повністю згоден(а)». Основний блок питань був поділений на 5 групи:

- Група організації навчального процесу (питання №1 -5);

- Група матеріально-технічного забезпечення навчальних занять (питання №6-10); 
- Група самостійного оцінювання досягнень у навчанні (питання №11$18)$;

- Група взаємодії з викладачами (питання №19-23);

- Група професійно-орієнтованої підготовки (питання №24-26).

За кожною із груп запитань середній рівень задоволеності був наступним: організація навчального процесу $-2,29 \pm 0,33$, мода -2 , тобто «я частково згоден(а)»; матеріально-технічне забезпечення навчальних занять $1,8 \pm 0,26$, мода - 1 , тобто «я не згоден(а)»; самостійне оцінювання досягнень у навчанні - 2,26 $\pm 0,09$, мода - 2, тобто «я частково згоден(а)»; взаємодія із викладачами - 2,36 $\pm 0,27$, мода - 3, тобто «я згоден(а)»; професійноорієнтована підготовка $-1,75 \pm 0,24$, мода 1 , тобто «я не згоден(а)». Графік 4 наочно демонструє отримані результати. Коефіцієнт варіації становить 15\%, що свідчить про однорідність результатів.

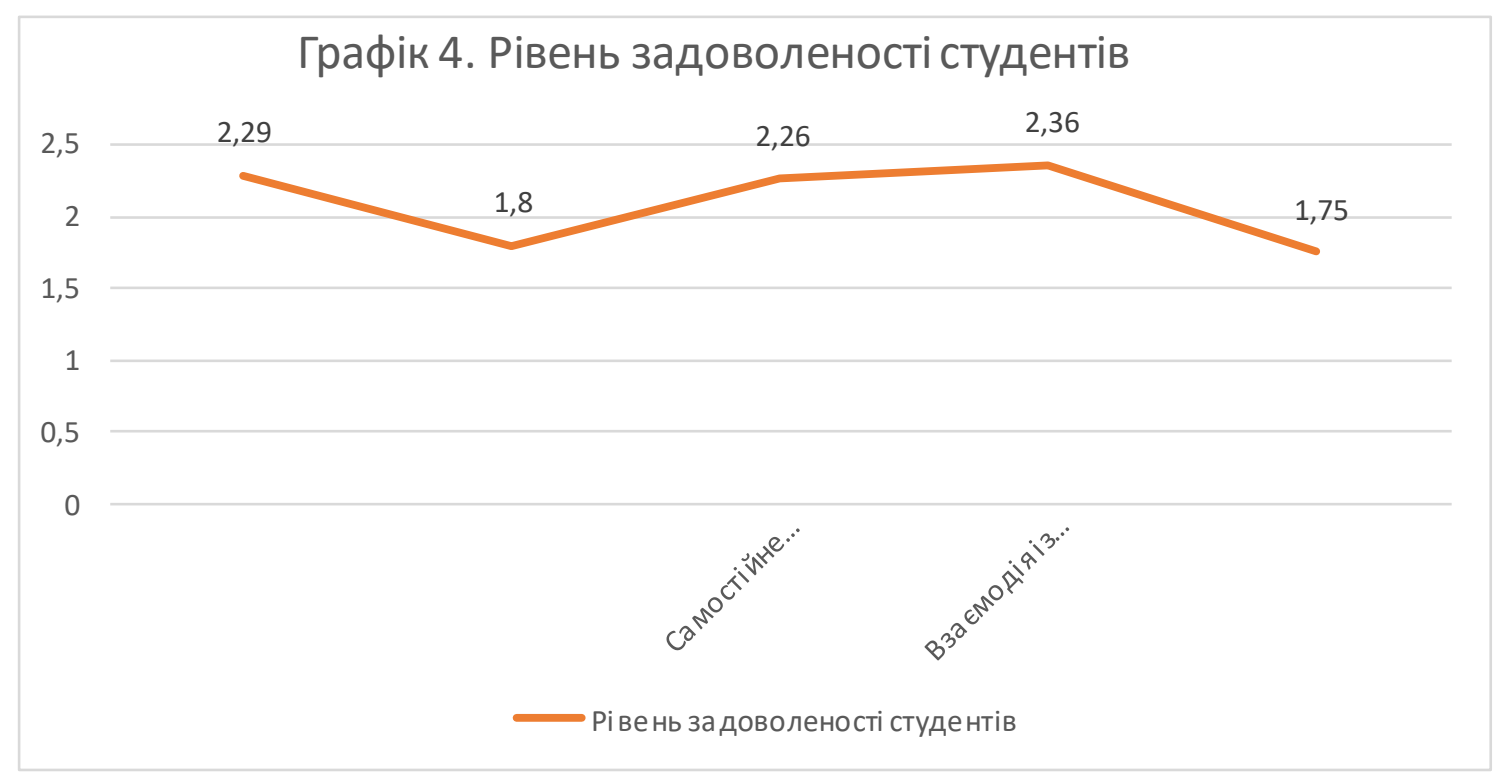

Загальну тенденцію відповідей, яка свідчить про сумарний середній рівень задоволеності студентів ФПЛЗСУ програмою дисципліни «Фізичне виховання», порушують питання із значним відхиленням відповідей. Необхідно звернути увагу на питання №5 «Мені вдається ефективно опрацювати матеріал, винесений на самостійне опрацювання», де студенти продемонстрували низький рівень задоволеності - розподіл відповідей на графіку 5. 
Графік 5. Розподіл відповідей на запитання "Мені вдається ефективно опрацювати матеріал, винесений на самостійне

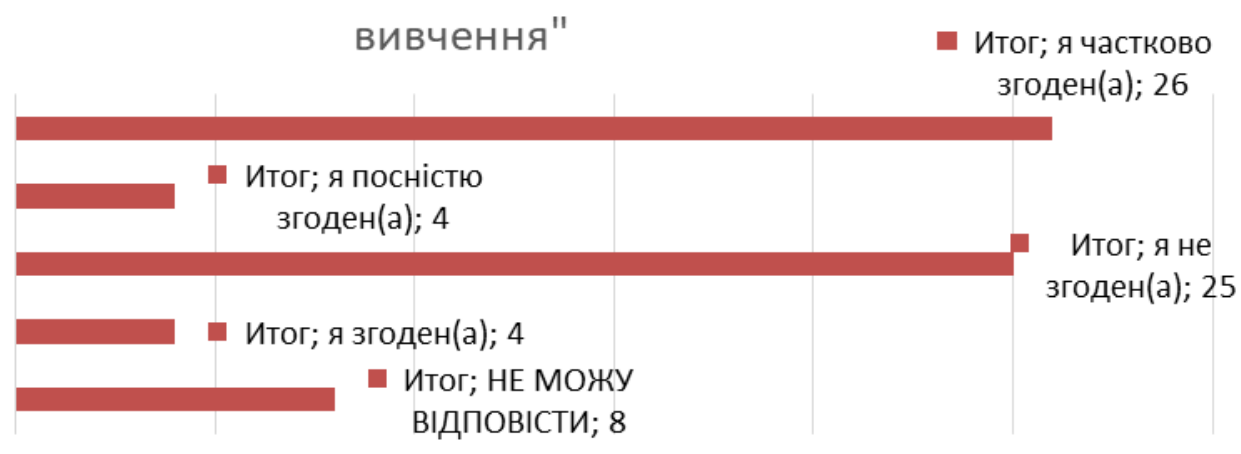

У запитанні №22 «Мені вдається успішно скласти всі нормативи» студенти переважно обирали варіанти, що відповідають вищому рівню задоволеності, а, отже, - їхній кращій фізичній тренованості, - графік 6

Графік 6. Розподіл відповідей на питання "Мені вдається успішно скласти всі нормативи"

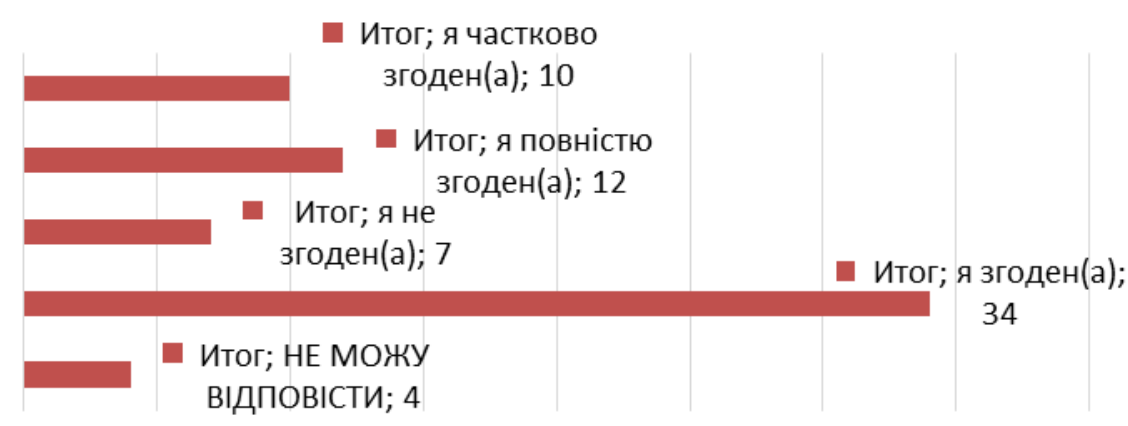

Обговорення: Описане дослідження є частиною дисертаційної роботи, присвяченої науковому обгрунтуванню організації фізичного виховання для студентів факультету підготовки лікарів для Збройних Сил України.

Незважаючи на актуальність зворотного зв'язку від студентів при формуванні програми викладання дисциплін, вітчизняні дослідження недостатньо висвітлюють зазначену тематику. На противагу, оцінювання задоволеності студентів стало good practice (хорошою практикою) у багатьох університетах світу (Why student satisfaction is key to the student recruitment, n. d.).

Використана у даній роботі методика дозволяє оцінити загальний рівень викладання дисципліни, а також основні фактори, що впливають на 
задоволеність студентів. Подальші дослідження повинні визначити внутрішні психологічні фактори, що впливають на формування суджень студентів, а також сприяти ефективному покращенню їхньої фізичної підготовки 3 урахуванням основних результатів поточної роботи.

Висновки. У даній статті описано дослідження оцінки задоволеності студентів факультету підготовки лікарів для Збройних Сил України Національного медичного університету імені О. О. Богомольця рівнем фізичної підготовки під час навчання. Основні результати роботи дозволять зробити наступні висновки:

- Використана методика поєднання міжнародного апробованого опитувальника Students' Learning Satisfaction Questionnaire та авторської анкети, розробленої за його принципами, дозволяє ефективно визначити рівень задоволеності студентів фізичної підготовкою під час навчання;

- Контингент студентів факультету підготовки лікарів для Збройних Сил України представлений особами iз високими досягненнями на попередніх рівнях здобуття освіти;

- Загальна задоволеність студентів дисципліною «Фізична підготовка» знаходиться на середньому рівні (переважна білість відповідей перебуває у діапазоні між «я частково згоден(а)» та «я згоден(а)»);

- Найвищі показники задоволеності студентів припали на групу питань, що описують взаємодію із викладачами;

- Найнижчі показники задоволеності зареєстровані за категоріями матеріально-технічного забезпечення навчальних занять та професійноорієнтованої підготовки.

\section{ЛІТЕРАТУРА:}

Butt B. Z., Rehman K. A. Study examining the students satisfaction in higher education. Procedia-Social and Behavioral Sciences. 2010. №2. P. 5446-5450.

Coffman D. L., Gilligan T. D. Social support, stress, and self-efficacy: Effects on students' satisfaction. Journal of College Student Retention: Research, Theory \& Practice. 2002. №4 (1). 53-66.

Dennis C., Papagiannidis S., Alamanos E., Bourlakis M. The role of brand attachment strength in higher education. Journal of Business Research. 2016. №69 (8). P. 3049-3057.

Mason R., Weller M. Factors affecting students' satisfaction on a web course. Australasian Journal of Educational Technology. 2000. №16. P. 2. 
Nauta M. M. Assessing college students' satisfaction with their academic majors. Journal of Career Assessment. 2007. №5(4). P. 446-462.

Topala I., Tomozii S. Learning satisfaction: Validity and reliability testing for students' learning satisfaction questionnaire (SLSQ). Procedia-Social and Behavioral Sciences. 2014. № 128. P. 380-386.

Why student satisfaction is key to the student recruitment. Retrieved from: https://www.qs.com/why-student-satisfaction-is-the-key-to-student-recruitment/

Кобець В. М. Задоволеність студентів майбутньою професією як емоційна складова самоефективності. Педагогічні науки: теорія, історія, інноваційні технології. 2012. №8. С. 260-268.

Маляр Е. І., Будний В. С. Професійно-прикладна фізична підготовка студентів у системі вищої професійної освіти. Педагогіка, психологія та медико-біологічні проблеми фізичного виховання і спорту. 2009. №12. С. 120-122.

Пустолякова Л. М., Болгар М. А., Павліченко С. В. Спортивні ігри як активний метод формування професійно-прикладних якостей майбутніх медиків на заняттях 3 фізичного виховання зі студентами медичного ВНЗ. Спортивное воспитание $u$ cnорт в ВУЗах. 2014. №6. С. 160-163.

\section{REFERENCES:}

Butt, B. Z. \& Rehman, K. A (2010) Study examining the students satisfaction in higher education. Procedia-Social and Behavioral Sciences. 2. 5446-5450.

Coffman, D. L. \& Gilligan, T. D. (2002) Social support, stress, and self-efficacy: Effects on students' satisfaction. Journal of College Student Retention: Research, Theory \& Practice. 4 (1). 53-66.

Dennis, C., Papagiannidis, S., Alamanos, E. \& Bourlakis, M. (2016) The role of brand attachment strength in higher education. Journal of Business Research. 69. 3049-3057.

Kobets, V. M. (2012). Zadovolenist studentiv maibutnoiu profesiieiu yak emotsiina skladova samoefektyvnosti. [Students' satisfaction with future profession as an emotional part of self-effectiveness] Pedahohichni nauky: teoriia, istoriia, innovatsiini tekhnolohii. 8. 260268. (in Ukrainian)

Maliar, E. I. \& Budnyi, V. Ie. (2009). Profesiino-prykladna fizychna pidhotovka studentiv u systemi vyshchoi profesiinoi osvity. [Professional-applied physical preparation of students in the system of higher professional education] Pedahohika, psykholohiia ta medyko-biolohichni problemy fizychnoho vykhovannia $i$ sportu. 12. 120-122. (in Ukrainian)

Mason, R. \& Weller, M. (2000) Factors affecting students' satisfaction on a web course. Australasian Journal of Educational Technology. 16. 2.

Nauta, M. M. (2007) Assessing college students' satisfaction with their academic majors. Journal of Career Assessment. 5(4). 446-462.

Pustoliakova, L. M., Bolhar, M. A. \& Pavlichenko, S. V. (2014) Sportyvni ihry yak aktyvnyi metod formuvannia profesiino-prykladnykh yakostei maibutnikh medykiv na zaniattiakh z fizychnoho vykhovannia zi studentamy medychnoho VNZ. [Sports games as an active method of forming professional and applied qualities of future physicians in physical education classes with medical students]. Sportyvnoe vospytanye y sport v VUZakh. 6. 160-163. (in Ukrainian)

Topala, I., \& Tomozii, S. (2014) Learning satisfaction: Validity and reliability testing for students' learning satisfaction questionnaire (SLSQ). Procedia-Social and Behavioral Sciences. 128. 380-386.

Why student satisfaction is key to the student recruitment. (n. d.). Retrieved from: https://www.qs.com/why-student-satisfaction-is-the-key-to-student-recruitment/ 
Інформація про автора:

Поливач Віктор Миколайович: ORCID: http://orcid.org/0000-0003-0155-7284, заступник ректора 3 адміністративногосподарських питань Національного медичного університету імені О.О. Богомольця, м. Київ, бульвар Т. Шевченка, 13, Україна, 01601. E-mail: v.n.pol@ukr.net
Information about the author:

Polyvach Victor: ORCID:

http://orcid.org/0000-0003-0155-7284, Deputy

Rector on Administrative and Economic Issues

of the Bogomolets National Medical

University, Kyiv, 13, T. Shevchenko

Boulevard, Ukraine, 01601.

E-mail:v.n.pol@ukr.net

Цитуйте цю статтю як: Поливач В. М. Методика та роль визначення суб'єктивної оцінки якості фізичного виховання студентів факультету підготовки лікарів для Збройних Сил України як фактор покращення системи освіти військових лікарів. Теорія та методика навчання та виховання. 2019. № 46. C. 92-103. DOI: 10.34142/23128046.2019.46.07

Дата надходження статті до редакції: 28.03.2019

Стаття прийнята до друку: 11.04.2019 